\title{
DCF Fair Value Valuation, Excessive Assetes and Hidden Inefficiencies
}

\author{
Paweł Mielcarz' ${ }^{1}$ Paweł Wnuczak
}

ABSTRACT

\begin{abstract}
Fair value concept is widely used in DCF (Discounted Cash Flow) business valuation. One of the main principle of fair value concept is full information symmetry between contracting parties. The assumption enforces specific way of FCF (Free Cash Flow) estimation: all areas of inefficiency of valuated companies should be identified and their effect on free cash flow should be eliminated. The projection of free cash flow thus prepared should reflect the optimum operations of the business. The methodological issues of fair value valuation of inefficient companies are not comprehensibly addressed in the financial and accounting literature. There is easily observable gap between fair value theory and valuation practices. Thus this article is an attempt to answer the question about practical issues in fair value valuation of companies which do not apply value based management rules. It is based on literature review, theory examination and short case studies which present proposed solution for practical problems. Methods of identification and assessment of impact of inefficiencies on the fair value of a business are hereinafter presented and supported with arguments.
\end{abstract}

KEY WORDS: $\quad$ fair value, non-operating assets, valuation of a business,

JEL Classification: $\quad$ G30

${ }^{1}$ Kozminski University, Poland

\section{Introduction}

The concept of fair value is used in accounting and business finance for defining an objective value of a given asset. Both the Accounting Act and the International Accounting Standards (IAS) use similar definitions of fair value. Article 28 (6) of the Accounting Act defines fair value as „(...) the amount for which a given asset could be exchanged or a liability repaid on an arm's length basis between interested, well-informed and non-related parties." The similar definition of fair value is provided in IAS 2.6 and repeated in other standards many times.

The new definition of fair value, as stated in 5 of Statement of Financial Accounting Standards (SFAS)

Corespondence concerning to this article should be addressed to: pawelw@alk.edu.pl
157 "is the price that would be received to sell an asset or paid to transfer a liability in an orderly transaction between market participants at the measurement date" (Benson, 2008: 102).

The contemporary theory of finance posits that valuation of a whole business should be based on the fair value concept, just like in the case of assets of various kinds (Pratt \& Niculita, 2008). This postulate seems particularly justified in a case when valuation is supposed to lead to the determination of the objective value not distorted by asymmetric access of parties to information and market inefficiency.

Provisions of IAS 39, 40 and 41 and IFRS (International Financial Reporting Standards) 3 state that the market price quoted in an active market is the most accurate approximation of the fair value of a given asset. In addition, IAS 38.7 points to liquidity as one of the 

ing assets might be important from the management or strategic point of view but it does not influence the result of valuation. In all cases, taking into consideration closed forecast of FCF, the assets ought to be treated in the same way in valuation.

Issues related to the adjustment for inefficiencies in the fair value valuation have been split into the following subjects for the purposes of this paper:

1) cash and its equivalents on the fair value of the entity valued;

2) assets generating income, but not related to core operations, on the fair value valuation of the business;

3) assets required for operations characterized by a functionality or capacity exceeding the needs of the business on the fair value valuation of such business;

4) non-operating assets not required for business purposes and not generating any income on the fair value valuation of the business;

5) cost inefficiency on the fair value valuation of the business;

6) inefficient sources of financing with equity for the purposes of fair value valuation;

7) inefficiency of cost of capital structure on the fair value valuation of the business.

\section{Estimation of effect of cash and its equivalents on the fair value valuation of a company}

In the business practice, consultants often treat cash as a required asset used for operations in the valuation process. They consider cash as an asset, in absence of which the business cannot conduct operations. The other approach is separation of cash balance on optimal cash level (operating cash) and on possible surplus (non-operating cash) or possible deficit (requires additional investment).

These approaches to valuation, however, seem to be not consistent both with fair value valuation standard and general framework of DCF method. The example below presents the issue of treatment of cash in FCFbased valuation.

\section{Example 1}

A business holds 2,000 monetary units (m.u.) at time 0 . Free cash flow for all the financing parties (Free Cash Flow to Firm - FCFF) has been estimated for the purposes of the DCF valuation of the company. The calculation of
FCFF required, among other things, forecast of demand for working capital calculated as difference between the change in balance of non-cash current assets (inventories and receivables) and change in non-interest liabilities. The FCFFs discounted using the Weighted Average Cost of Capital (WACC) resulted in the value of business, including the debt but without opening balance of cash, (V) amounting to 4,981 m.u. Assumptions and calculations underlying the example are provided in the table 1.

When a company is valued using DCF method, the amount of the future cash flow potentially generated by the entity is first determined. The value of such cash flow incorporates the amount of required working capital expenditures calculated as the difference between the change in balance of non-cash working assets (inventories and receivables) and short-term liabilities. Therefore, an estimation of future free cash flows takes into account the need for increase of cash in order to guarantee the proper amount of working capital. If we adopt the assumption that working capital expenditures have been properly estimated, the purchase price of the business is reduced adequately to the need for addition to the working capital. The new owner of the business will therefore pay an accordingly lower amount in exchange for providing liquidity for the company. In this context, the whole of the opening cash balance should be considered an additional asset to the value of discounted free cash flow from future business operations in the preset scenario. Opening balance of cash should not can be treated as non operating assets from strategic or management perspective. Any need for additional cash to finance future business operations is already reflected in FCF forecast.

Such approach imposes adding the total cash balance to the valuation of assets generating free cash flow. The value of the business including debt $(\mathrm{V})$ will then rise to 6,981 m.u (table 1). Omission of this operation would lead to significant underestimation of company's value. The buyer would then become owner of an organized business generating free cash flow plus cash at hand and in banks for the price of future free cash flow only (without paying for cash that it would own).

Some practitioners argue that a certain level of free cash must be maintained in the company in case of a sudden change of market condition which could also change future free cash flow. The question therefore 
Table 1. Assumptions underlying the valuation

\begin{tabular}{|c|c|c|c|c|}
\hline Period & 0 & 1 & 2 & 3 \\
\hline Opening cash balance & 2,000 & & & \\
\hline Inventory balance & 100 & 110 & 122 & 135 \\
\hline Receivable balance & 200 & 230 & 265 & 305 \\
\hline Balance of non-interest liabilities & 150 & 158 & 165 & 175 \\
\hline Expenditures on non-cash working capital & & -32 & -40 & -43 \\
\hline Period & 0 & 1 & 2 & 3 \\
\hline NOPAT & & 1,000 & 1,200 & 1,250 \\
\hline Expenditures on working capital & & -32 & -40 & -43 \\
\hline Capital expenditures & & $-1,500$ & -100 & -100 \\
\hline Residual Value & & & & 5,000 \\
\hline FCFF & & -532 & 1,060 & 6,107 \\
\hline WACC & & \multicolumn{3}{|c|}{$10 \%$} \\
\hline DFCFF & & -484 & 876 & 4,588 \\
\hline V (value of the business) & 4,981 & & & \\
\hline Opening cash balance & 2,000 & & & \\
\hline V (value of the business) + cash & 6,981 & & & \\
\hline
\end{tabular}

arises if value of expenditures on setup of a security cash balance should be added to working capital expenditures or a part of opening cash balance should be considered operating cash in valuation process. We believe that answers to both questions ought to be negative. Consideration of some of cash balance as operating assets or inclusion of expenditures on cash into working capital expenditures on account of future events not covered by the FCF forecast are in practice an attempt to embed the risk analysis into the base variant of the valuation. On the other hand the methodological correctness requires separation of valuation from risk analysis.

The fair value principle requires a FCF projection based on the most probable assumptions. Therefore it should present the most probable scenario of future free cash flow of valuated company. Expected values of specific assumptions in FCF estimation are, of course, sensitive to the effect of risk, so the base variant of valuation takes the risk into account to some extent. If, however, the analyst can see serious threats making specific assumptions highly risky (resulting in flattened or multimodal distributions of value of each assumption), their effect on the valuation should be taken into account by means of an additional sensitivity or scenario analysis. In other words, working capital demand different than the assumed in most probable scenario of valuation should be taken into account by means of alternative valuations scenario rather than consideration of cash as operating assets in most probable scenario of valuation.

The analysis of free cash flows presented in example 1 may also give rise to doubts concerning the opening cash balance consideration as an additional asset to the value of discounted free cash flow in the face of the required financing of high expenditures in year 1 . In this year value of the free cash flow falls below zero (FCF (-) 532). It must be, however, clearly stated that the value of the company will also fall as a result of negative FCF value. It means that the price paid by the prospective buyer will therefore be reduced by the amount that he or she will have to spend on financing of planned expenditure. Opening balance of cash cannot therefore be considered as source of financing of future investment projects. Once again, it is another situation when the whole cash has to be considered as additional asset to the value of discounted free cash flow. 
Presented approach to the cash treatment in fair value valuation imposes correction of cost of capital used in valuation process. Due to the fact that cash is treated as a separated asset to the value of discounted free cash flow from future business operations, the cost of capital should reflect only the risk of operational assets (Damodaran, http://pages.stern.nyu.edu). In this circumstances the cost of capital will increase as beta of cash is equal $0 .^{1}$

Rules of treatment of cash equivalents in DCF valuation should also be discussed. According to IAS 7, cash equivalents are designed to pay short-term liabilities rather than finance investments. They are characterized by high liquidity, short payment term (up to three months) and low risk of loss of value. In practice, they include deposits and short-term debt securities generating relatively low rates of return and easily convertible to cash.

Just like cash, cash equivalents should be treated as an additional asset to the value of discounted free cash flow in valuation process. Such solution would mean the need for non-inclusion of benefits from maintenance of funds in the form of cash equivalents into the projection of free cash flow. This approach is correct from the perspective of the fair value concept provided that the rate of return on cash equivalents is lower than the discount rate. In such situation, value earned on the immediate monetization of cash equivalents will be higher than the present value of benefits from maintenance of funds in the form of cash equivalents spread in time. Taking low rate of return on cash equivalents into account, it will mean that inclusion of their liquidation value into additional asset to the value of discounted free cash flow will be grounded in a great majority of cases.

\section{Estimation of effect of non-oper- ating assets generating income on the fair value valuation of a company}

Non-operating assets generating income can be split into:

1) assets generating income and not related to the core business of the enterprise, e.g. separated and not occupied by the valuated company parts of office buildings, production halls or warehouses that can be leased out.

2) financial investments (e.g. debt securities or shares in other companies);
The of the valuation approach to income-generating non-operating assets depends on the difference between rate of return on such assets and the rate of return expected by capital providers applied to discounting process of free cash flow. The general rule related to valuation of income-generating non-operating assets within an undetermined time can be worded as follows:

1) if the FCF rate of return on non-operating assets is lower than the rate of return expected by capital providers applied to discounting of future free flow in the unforeseeable future, the market value of the income-generating asset should be added to the value of discounted free cash flow of the company from the core business. At the same time the FCF generated by such assets should be excluded from the estimation of future free cash flow for the purposes of business valuation; the said relation can be expressed as follows:

$$
\frac{F C F F a}{M V a}<W A C C<=>\begin{aligned}
& \text { disclosure of market } \\
& \text { value of assets within } \\
& \text { non-operating assets }
\end{aligned}
$$

where FCFFa is the average value of the planned free cash flow from the asset valued; MVa is the market value of the asset valued; and WACC is the weighted average cost of capital applied to the valuation of the whole business;

2) if the FCF rate of return on non-operating assets is higher than the rate of return expected by capital providers applied to discount of free cash flow in the unforeseeable future, FCF generated by such assets should be considered as part of free cash flow of the business for the purposes of valuation of a company; the said rule can be expressed as follows:

$$
\frac{F C F F a}{M V a}>W A C C<=>\begin{aligned}
& \text { disclosure of FCFF } \\
& \text { from assets in the FCFF } \\
& \text { of the business valued }
\end{aligned}
$$

3) if the FCF rate of return on non-operating assets is equal to the rate of return expected by capital providers applied to discount of free cash flow in the unforeseeable future, any of the above methods can be used for the purposes of valuation of the whole business. 
Table 2. Assumptions underlying the valuation and valuation of non-operating assets

\begin{tabular}{|l|l|l|l|}
\hline & variant 1 & variant 2 & variant 3 \\
\hline Market value of the asset & $\mathbf{1 0 , 0 0 0}$ & $\mathbf{1 0 , 0 0 0}$ & $\mathbf{1 0 , 0 0 0}$ \\
\hline Yearly value of free cash flow & 500 & 1,000 & 1,500 \\
\hline Rate of return on the income-generating asset & $5 \%$ & $10 \%$ & $15 \%$ \\
\hline WACC & $10 \%$ & $10 \%$ & $10 \%$ \\
\hline $\begin{array}{l}\text { Effect of valuation of the asset using DCF-based approach on the } \\
\text { valuation of the whole business }\end{array}$ & $\mathbf{5 , 0 0 0}$ & $\mathbf{1 0 , 0 0 0}$ & $\mathbf{1 5 , 0 0 0}$ \\
\hline
\end{tabular}

The relations described above are illustrated by Example 2 .

\section{Example 2}

A business has a holiday center for its employees generating free cash (values for each variant are shown in the table 2). The market value of the center amounts to 10,000 m.u. The rate of return expected by capital providers of the company (WACC) amounts to $10 \%$.

The present value of perpetual free cash flow earned on the holiday center has been determined for each variant ${ }^{2}$. The following results have been obtained accordingly for each variant: 5,000 m.u. (quotient of the yearly value of FCF (500 m.u.) and WACC rate (10\%), 10,000 m.u. and 15,000 m.u. Moreover, the rate of return on assets has been determined for each variant by dividing the yearly value of FCF from vacation centers by their market value (the results were $5 \%, 10 \%$ and $15 \%$, accordingly). The above results allow us to draw the following conclusions:

1) in variant 1 (table 2), market value of the center $(10,000$ m.u.) exceeds the present value of FCF generated by the center (5,000 m.u.); the vacation center should therefore be considered a non-operating asset for the purposes of valuation of the business in accordance with fair value standards; inclusion of free cash flow generated by the center into the valuation of the business would lead to its undervaluation; the rate of return on the center (5\%) is lower than the rate of return expected by capital providers applied to discount of free flow of whole company (10\%);

2 ) in variant 2 (table 2), market value of the center $(10,000$ m.u.) is equal to the present value of FCF generated by the center (10,000 m.u.); the holiday center can therefore be considered a non-operating asset or an element generating free cash flow for the purposes of valuation of the business; the rate of return on the center $(10 \%)$ is equal to the rate of return expected by capital providers applied to discount of free flow (10\%);

3 ) in variant 3 (table 2), market value of the center (10,000 m.u.) is lower than the present value of FCF generated by the center $(15,000$ m.u.); the holiday center should therefore be considered an element generating free cash flow for the purposes of valuation of the business (its consideration as a nonoperating asset would lead to undervaluation of the business); the rate of return on the center (15\%) is higher than the rate of return expected by capital providers applied to discount of free flow (10\%).

The presented reasoning proves the veracity of the relation between the rate of return on assets and the weighted average cost of capital presented above.

FCF-generating financial investments should be similarly treated in the business valuation process. The present value of FCF generated by such assets should be determined in order to define the way of their inclusion in the valuation of a business. If:

1) market value of such assets exceeds the present value of FCF generated by such assets, they should be considered non-operating assets and added to the valuation of the business calculated based on discounted free cash flow obtained from main activities;

2) market value of such assets is lower than the present value of FCF generated by such assets, they should be considered an element generating free cash flow of the business. 
Table 3. Valuation of securities for the purposes of valuation of the whole business

\begin{tabular}{|l|l|l|l|l|}
\hline Period & 0 & 1 & 2 & 3 \\
\hline Present market value of bonds & 2,000 & & & \\
\hline Coupon rate & $5 \%$ & & & \\
\hline Rate of return expected by capital providers (WACC) & $15 \%$ & & 100 & 2,100 \\
\hline Free cash flow from maintenance of bonds until maturity & & 100 & $\mathbf{1 , 3 8 1}$ \\
\hline $\begin{array}{l}\text { Discounted value of free cash flow from maintenance of bonds } \\
\text { until maturity - discounted cash flow }\end{array}$ & $\mathbf{8 7}$ & & & \\
\hline $\begin{array}{l}\text { Present value of cash flow from maintenance of bonds until } \\
\text { maturity }\end{array}$ & $\mathbf{1 , 5 4 3}$ & & & \\
\hline
\end{tabular}

Source: Own study

Example 3 presents the method of inclusion of nonoperating assets generating income in a specified time in the valuation of the business.

\section{Example 3}

A business holds debt securities, the market value of which amounts to 2,000 m.u. We know that they guarantee a yearly return of 5\% for the three years to come. The securities will be bought back at the nominal price (2,000 m.u.) at the end of year 3. The rate of return expected by capital providers amounts to $15 \%$. Assumptions and calculations underlying the example are provided in the table 3.

Financial FCF generated by bonds will amount to 100 m.u. yearly ( $5 \%$ of 2,000 m.u.). The present value of financial FCF and the present value of the buy-back price of the bonds should be determined in order to define the way of their inclusion in the valuation of the business. In the example discussed, if WACC of whole company is applied the present value of all free cash flows related to debt securities amounts to 1,543 m.u. and is lower than the market value of the asset at time 0 . Debt securities should therefore be considered an additional asset to the value of discounted free cash flow from business operations. It means that market value of the bonds should be added to the value of discounted free cash from future operations and any FCF generated by the securities should be withdrawn from estimation of business $\mathrm{FCF}^{3}$.

In summary, the way of inclusion of income-generating non-operating assets in the business valuation process depends on the present market value of such assets and the present value of all cash flows generated by such assets.

\section{Estimation of effect of excessive assets required for operations on the fair value valuation of the business}

Excessive assets required for operations can include assets used by the company for day-to-day business, but exceeding the relevant needs of the business in terms of functionality and potential. The said assets may encompass:

1) business offices situated in town centers, the high standard of which does not affect the ability of the business to generate free cash flow;

2) production halls situated in attractive (expensive) places, if such situation is not required for the purposes of generation of free cash flow;

3) machinery and devices, the potential and capacity of which are not fully used by the business.

Three scenarios of inclusion of such assets in DCF valuation should be considered for the purposes fair value valuation:

1) sale of non-operating assets at the market price and lease of assets equally well adapted to the business needs, if such asset can be leased;

2) sale of non-operating assets at the market price and purchase of assets equally well adapted to the business needs, if such asset can be purchased;

3) consideration of such non-operating asset as required for business purposes, if no asset better adapted to the business needs can be found. 

Assets related to operations and able to be separated from the operating point of view, but not sufficiently used, are another group of assets not generating any income. If this is the case, the separated part should be priced as the present value of cash flow from lease of such assets or as value of their resale, if technically possible, for the purposes of fair value business valuation. If separated assets can be either sold or leased, higher value for the owners should be the basis of fair value valuation.

In summary, assets not required for business purposes and not generating any income are not a homogenous group from the point of view of their inclusion in the fair value business valuation.

\section{Estimation of effect of cost inef- ficiency on the fair value valuation of the business}

When fair value is estimated using the DCF approach, the expert valuing the business should make, among other things, effort so that valuation is based on cash flow not including any inefficiencies hidden in the costs incurred by the business. Such inefficient cost mainly include:

1) non market, excessive salaries;

2) excessive cost of salaries resulting from failure to align the headcount structure with the scope of business;

3) consumption of production factors exceeding standards due to inefficiencies or lack of employees skills (e.g. consumption of production materials exceeding standards);

4) non-market contracts with vendors (e.g. when the amount of a contract is affected by factors different than financial reasonability);

5) transfers to owners hidden in costs that are return on capital invested rather than remuneration for their work.

The inclusion of the above inefficiencies into the free cash flow will lead to reduction in value of such free cash flow resulting in undervaluation of fair value of the entity. Free cash flow should therefore be netted of unreasonable costs in order to estimate the fair value of the business. It will be, however, very difficult in many cases. For instance, relatively high headcount and salaries may be due to a deliberate policy of the management. Deployment of such policy may result in a rise in quality of products enabling the business to get competitive advantage. Reduction in salaries and headcount could lead to deterioration in quality of products offered, loss of some sales markets and, therefore, to a decline in cash flow generated by the firm. In such situation, relatively high salaries and relatively high headcount are elements of strategy deployed by the firm and supposed to lead to a rise in its value rather than sources of inefficiencies. As the above example shows, identification of inefficiencies hidden in costs may be difficult to do in some cases. Mistakes made in the process of identifying such unreasonabilities lead to wrong valuation of fair value of businesses. Expert valuing a business should therefore exclude obvious and well-documented inefficiencies only, e.g. consumption of production materials exceeding standards as confirmed by the company technologist

\section{Elimination of effect on inefficient sources of financing with equity for the purposes of fair value valuation}

Cost of equity is one of the basic parameters affecting the value of a company. In practice, it may depend on many factors including expectations of entities involved in the transaction or periodic disturbances of financial markets. The nature of owners can affect the expected rate of return, too. For example, an entity owned by a Private Equity fund will incur a much higher cost of equity than an entity owned by diversified shareholders.

The way of estimation of fair cost of equity should be agreed in order to eliminate inefficiency related to excessively high cost of equity from fair value valuation. It should be based on an analysis of assumptions underlying the fair value concept, the Portfolio Theory and the Capital Assets Pricing Model.

The assumption of an unlimited number of buyers and sellers is fundamental for determination of the expected fair rate of return (cost of equity) that could be used for valuation in accordance with the fair value standard. The above assumption leads to the conclusion than the "objective" expected rate of return should be insensitive to the liquidity level of a given asset as a fully active market creates no liquidity problems. However, since the presence in such market of investors who diversify their risk in accordance with the assumptions of the portfolio theory of H. Markowitz (1952: 77-91) 
Figure 1. Justification of use of the CAPM for estimates of the expected rate of return for the purposes of fair-value valuation

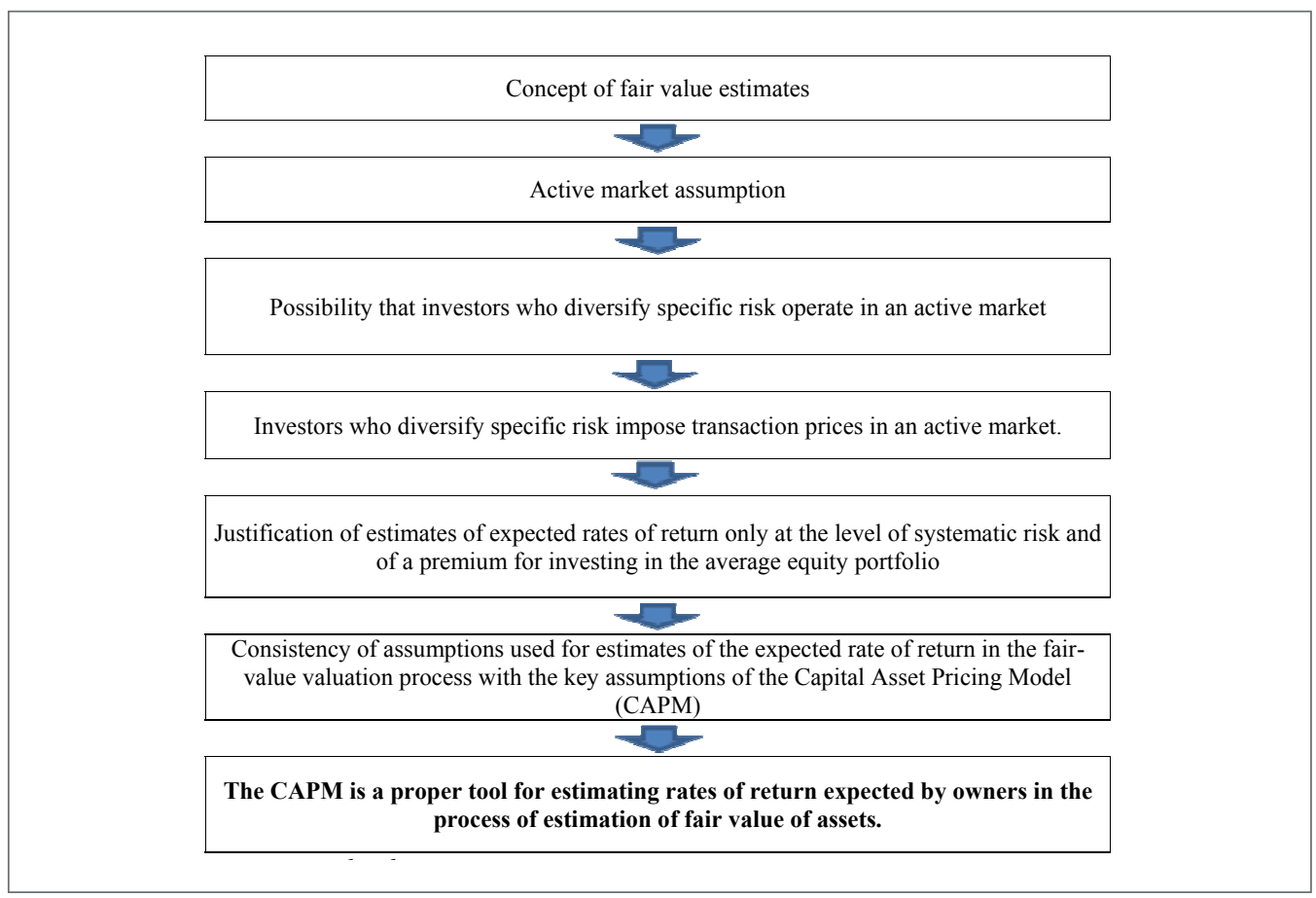

cannot be ruled out, the rate that would allow for determination of fair value of a given asset should neither include a premium for specific risk (Sharpe, 1964: 425442). Elimination of the specific risk leads to a reduction in expected rate of return on investment in a given asset to a level reflecting its systematic risk, premium for investing in equity instruments and the risk-free rate only ${ }^{6}$. Assumptions of existence of an active market and of a possibility to reduce specific risk by means of diversification of the investment portfolio and, consequently, justification of a premium for capital at the level of systematic risk connected to given asset only are fully in accordance with the assumptions underlying the Capital Assets Pricing Model (CAPM). Therefore, there are arguments in favor of the conclusion that the CAPM is a suitable tool for determination of the objective rate of return expected by shareholders that should be used for estimation of fair value valuation of a given business (Mielcarz \& Paszczyk, 2010: 124-125). According to survey studies conducted by Graham and Harvey (2001), the Capital Asset Pricing Model (CAPM) is the most common method favored by practitioners in estimating the equity cost of capital.

\section{Estimation of effect of inefficiency of structure and cost of capital on the fair value valuation of the business}

The problem of optimization of corporate capital structure is one of the central problems of corporate finance and has important applications for practical decision-making concerning financing of current operations and investment projects of corporations (Philosophov \& Philosophov, 2005: 192). The investigation of the problem was initialized by the seminal papers of Modigliani \& Miller (1958, 1963), who studied the influence of tax advantage of debt financing on firms' capital structure decisions. According to Modigliani-Miller theory extended to include bankruptcy costs, the optimum structure of capital includes an equity and debts leading to maximization of value of a business (Ross, Westerfield \& Jaffe, 2008: 433-473). The widely known traditional theory also referred to as 
traditional approach assumes that the structure of capital of a business achieves its optimum at the minimum level of the weighted average cost of capital (WACC) (Dudycz, 2005: 133). This theory assumes that moderate indebtedness of a business does not lead to a material rise in risk and, consequently, rise in cost of capital. Moderate indebtedness should therefore lead to a decline in WACC resulting in increased value of the business. Shareholders, however, increase significantly their expectations concerning the rate of return on capital invested after a certain debt value threshold is exceeded (e.g. risk of non-payment of dividend grows). This causes a rise in cost of equity; WACC therefore grows. In that case, providers of debts also expect an increased rate of return on capital contributed to the company as the risk grows. Bearing the above mechanisms in mind, a business which is run according to value based management rules should incur debt until the minimum WACC is achieved in order to optimize its capital structure (Wnuczak, 2010: 148).

The concept of DCF valuation based on the FCFF approach clearly indicates that the structure of financing of a business affects its value. WACC is the discount rate used for determination of present value in the FCFF approach. Therefore, the lower WACC, the higher the present value of cash flow discounted and the value of the business.

Determination of the optimum structure of financing where WACC is minimized is therefore essential for the purposes of determination of the fair value of a business as a reasonable investor should take care of a financing structure leading to maximization of shareholder value according to assumptions underlying the fair value concept.

The need for application of minimum WACC in fair value valuation can be also explained in other way. In perfect fair value world there are unlimited number of potential sellers and buyers of any asset. It means that it cannot be ruled out that there are marginal investor invulnerable on any specific risk in the group of buyers. Due to their diversification they will be more concentrated on the highest rate of return than on the specific risk which comes from additional debt. Consequently they will force management of the company to keep optimum level of WACC. Lack of optimum WACC will lead to the undervaluation of the company shares and potential hostile takeover.
Two examples of practical techniques used for determination of such financing structure are described below. Nevertheless, it has to be stated that the theory of finance has not developed any methodologically consistent solutions in this area. The first consists in determination of the optimum financing structure by planning WACC at various levels of indebtedness and, therefore, determination of the moment when WACC is the lowest. The other approach makes it possible to determine the optimum financing structure based on market comparisons.

7.1. Determination of the optimum financing structure: definition of the financing structure for the minimum WACC

WACC can be calculated using the following formula:

$$
W A C C=\frac{D}{D+E} \times r_{d} \times(1-T)+\frac{E}{D+E} \times r_{e}
$$

where:

$D$ is the interest-bearing debt,

$E$ is the equity market value,

$r_{d}$ is the average interest rate on debt (cost of debt),

$r_{e}$ is the rate of return expected by the owners (cost of equity).

The structure leading to minimization of WACC, i.e. to optimization of the financing structure, can be found by substituting each variant of structure of financing of the company assets to the above formula. The cost of equity and debt should, however, be earlier estimated for various levels of indebtedness.

The cost of equity can be determined based on the Capital Asset Pricing Model (CAPM) where the rate of return expected by the shareholders is estimated based on the risk-free rate of return plus premiums for market risk and the company inherent risk. The formula making it possible to calculate the cost of equity can be expressed as follows:

$$
r_{e}=r_{f}+\mathrm{b}\left(r_{m}-r_{f}\right.
$$

where:

$r_{f}$ is the risk-free rate of return, 
$r_{m}$ is the expected market rate of return on investment in equity assets,

$\beta$ is the measure of market risk involved in investing in a given company.

The value of beta $(\beta)$ for various levels of indebtedness can be determined using R. Hamada's concept. R. Hamada (1972) proved that the beta value could be calculated using the following formula:

$\mathrm{b}=\mathrm{b}_{U}\left(1+(1-T) \frac{D}{E}\right)$

where:

$\beta$ is levered beta,

$\beta_{U}$ is unlevered beta.

As results from the above formula, beta depends on indebtedness. If levered beta $(\beta)$ and the current structure of financing of comparable listed companies are known, unlevered beta $\left(\beta_{U}\right)$ or the hypothetical beta for companies in one sector can be determined based on the assumption that the company does not finance its operations with any debt. To this end, the above formula should be transposed as follows (Wnuczak, 2011: 510):

$\mathrm{b}_{U}=\frac{\mathrm{b}}{\left(1+(1-T) \frac{D}{E}\right)}$

The unlevered beta $\left(\beta_{U}\right)$ calculated in this way can be used for determination of levered betas for various levels of debt to market value of equity using Hamada's theorem. Changes in cost of equity following changes in debt can therefore be calculated.

Cost of debt at various debt levels must be estimated in order to determine WACC for each level of indebtedness. Such estimate can be based on offers of banks or on an analysis of cost of debt incurred by other companies characterized by various debt levels. The practical problem of the first solution comes from the assumption underlying WACC theory and Hamada formula about use of market instead of book value of equity in beta and WACC calculation. Therefore it seems that analysis of the relations between yield to maturity of bonds of listed companies and their interest bearing debt to market equity value ratio is more feasible solution.
Knowledge of cost of equity and debt at various levels of indebtedness makes it possible to determine the structure of financing where WACC reaches its minimum. It will be the optimum financing structure that should be applied to the DCF business valuation process, too. Such approach makes it possible to determine the fair value of the entity valued.

\subsection{Determination of the optimum financing structure: market comparison approach}

The optimum financing structure can be determined based on structures of financing of other companies. Comparison of structure of capital of the company valued to that of similar companies is the essence of this approach. Companies active in the same sectors should be chosen for comparisons. Multiple studies (Wilmowska, Wilmowski \& Kopala, 2009) show that the optimum capital structure depends on the sector. Studies confirm (Wilmowska \& Kopala, 2010) that debt acceptable in some sectors is higher than that acceptable in others. Companies compared should in addition feature similar structures of revenues, costs and assets. However, the question arises if the company chosen for comparisons has the optimum financing structure. It will be very hard or even impossible to provide a clear answer. The assumption that listed companies should be managed in accordance with Value Based Management rules can, however, be adopted. Their asset financing structures should therefore be optimized so that their market value grows. This is shareholders' expectation.

The structure of financing of assets of various companies in a given sector may prove to be differentiated in many cases. Key reasons include their various characteristics, different perception of risk by owners and management and various business strategies. The assumption that the financing structure of a business valued should tend towards structures of financing of listed companies active in the same sector and forced to follow the shareholder value maximization rules can therefore be adopted for the purposes of determination of the optimum structure of capital of a business valued. It practically means deletion of entities listed, but not threatened by a hostile takeover from the list of benchmark entities since only entities threatened by a hostile takeover and, therefore, characterized by dispersed shareholding must in practice take care of the 
optimum capital structure. Absence of the optimum capital structure results in undervaluation of such entities leading to a hostile takeover attempt by entities noticing the non-optimum valuation of a given business.

\section{Conclusions}

The goal of the paper was to present practical solutions which allow to carry out fair value estimation of a company which is not run according to value based management rules. Absence of relevant adjustments leads to undervaluation of fair value of the business. It requires elimination of the bias caused by hidden inefficiencies, excessive assets and non-operating assets. The way of making such adjustment depends on the specificity and type of the inefficiency. Detailed approaches to eliminate impact of particular inefficiencies in fair value valuation of a business were presented in various sections of this paper.

\section{References}

1. Benson, G. J. (2006). Fair-value accounting: A cautionary tale from Enron. Journal of Accounting and Public Policy, 25 (2006), 465-484.

2. Benson, G. J. (2008). The shortcomings of fairvalue accounting described in SFAS 157. Journal of Accounting and Public Policy, 27 (2008), 101114.

3. Dudycz, T. (2005). Zarządzanie wartością przedsiębiorstwa. Warszawa: Polskie Wydawnictwo Ekonomiczne.

4. Graham, J.R. \& Harvey, C.R. (2001). The theory and practice of corporate finance: evidence from the field. Journal of Financial Economics, 60 (2001), 187-243.

5. Gołębiowski, G. \& Szczepankowski, P. (2007). Analiza wartości przedsiębiorstwa, Warszawa: Difin.

6. Hamada, R.S. (1972). The Effect of the Firm's Capital Structure on the Systematic Risk of Common Stocks. The Journal of Finance, 27(2), 435-452.

7. Helbling, C. (1995). Unternehmensbewertung Und Steuern. Dusseldorf: 8 Auflage, IDW Verlag.

8. Malinowska, U. (1999). Dochodowa czy majątkowa?, Nowe Życie Gospodarcze, $\mathrm{Nr}$ 19/1999.

9. Malinowska, U. (2001). Wycena przedsiębiorstwa w warunkach polskich. Warszawa: Dyfin.

10. Markowitz H. (1952). Portfolio Selection. The Journal of Finance, 7(1), 77-91.

11. Mielcarz, P. \& Paszczyk, P. (2010). Increasing Shareholders Value through NPV-Negative Projects. Contemporary Economics, No. 3/2010, 119130.

12. Sharpe, W. F. (1964). Capital asset prices: A theory of market equilibrium under conditions of risk. The Journal of Finance, 19 (3), 425-442.

13. Panfil, M., Szablewski A. (2006). Metody wyceny spółki perspektyw klienta i inwestora. Warszawa: Poltext.

14. Philosophov L.V. \& Philosophov V.L., Optimization of a firm's capital structure: A quantitative approach based on a probabilistic prognosis of risk and time bankruptcy. International Review of Financial Analysis, 14 (2005), 191-209.

15. Modigliani, F. F. \& Miller, M. H. (1958). The cost of capital, corporation finance and the theory of investment. The American Economic Review, 48, No 3, 267- 297.

16. Modigliani, F. F. \& Miller, M. H. (1963). Corporation income taxes and the cost of capital: A correction. The American Economic Review, 53, No. 3, 433-443.

17. Plenborg, T. (2002). Firm valuation: comparing the residual income and discounted cash flow approaches. Scandinavian Journal of Management 18 (2002), 303-318

18. Pratt, S.P. \& Niculita, A.V. (2008). Valuing a Business. The Analysis and Appraisal of Closely Held Companies. New York: McGraw Hill.

19. Ross, S., Westerfield, R. \& Jaffe, J. (2008). Corporate Finance. New York: McGraw Hill.

20. Szczepankowski, P. (2001). Poznawanie wartości własnego przedsiębiorstwa. Warszawa: Instytut Przedsiębiorczości i Samorządności.

21. Wilmowska, Z., Wilmowski, M. \& Kopala K. (2009). Financial value factors in VBM. Information systems architecture and technology: IT technologies in knowledge oriented management process. Wrocław: Oficyna Wydawnicza Politechniki Wrocławskiej.

22. Wilmowska, Z. \& Kopala, K. (2010). Wpływy wybranych czynników na strukturę finansową przedsiębiorstwa. Czas na pieniądz. Zarządzanie 
finansami. Analiza finansowa i zarządzanie ryzykiem. Zeszyt Naukowy nr 26. Szczecin: Uniwersytet Szczeciński.

23. Wnuczak, P. (2010). Struktura kapitału przedsiębiorstw notowanych na Giełdzie Papierów Wartościowych w Warszawie. Contemporary Economics, Nr 4/2010, 148.

24. Wnuczak, P. (2011). Zastosowanie ekonomicznej wartości dodanej (EVA) w procesie optymalizacji struktury kapitału przedsiębiorstwa. Czas na pieniądz. Zarządzanie finansami. Współczesne wyzwania teorii i praktyki, Zeszyt Naukowy nr 640, Szczecin: Uniwersytet Szczeciński.

\section{Notes}

1 Unlevered beta corrected for cash = Unlevered Beta/ (1 - Cash/ (Market Value of Equity + Market Value of Debt))

2 According to formula of the present value of perpetual annuities, $P V=F C F F / W A C C$, where $P V$ is the present value of perpetual payments.

3 This approach will give the same result for final value of the business as treatment of FCF generated by the bonds as a part of business FCF with usage of yield to maturity as discount rate of cash flow generated by the bonds.

4 Please also note that the examples analyzed are based on the underlying assumption of no adverse effect of transfer of the business to another place on the income generation capacity of the business. If there were any prerequisites for believing that the change of situation will result in customer harm or temporary problems with maintaining the existing level of operations, they would have to be taken into account in the business fair value calculation.

5 It should be emphasized again that addition of any non - operating assets value to the value of discounted FCF from core operation does not mean that buyer or seller must sell the assets. It only means that under the assumption of nonexistence of information asymmetry both contracting parties are aware of such possibility and therefore the value of non operating assets should be taken into consideration in fair value valuation.

6 Note that in a perfectly active market, investors limiting the specific risk of investments by means of diversification practically accept the lowest expected rates of return and, therefore, the highest transaction prices. They are, therefore, the group imposing terms of purchase onto others on an active market. 